\title{
Prolactin Levels Correlate with Abnormal B Cell Maturation in MRL and MRL/lpr Mouse Models of Systemic Lupus Erythematosus-Like Disease
}

\author{
Maria Victoria Legorreta-Haquet, ${ }^{1}$ Rocio Flores-Fernández, ${ }^{1,2}$ Francisco Blanco-Favela, \\ Ezequiel M Fuentes-Pananá, ${ }^{3}$ Luis Chávez-Sánchez, ${ }^{1}$ Rafael Hernández-González, ${ }^{4}$ \\ Emiliano Tesoro-Cruz, ${ }^{1,4}$ Lourdes Arriaga-Pizano, ${ }^{5}$ and Adriana Karina Chávez-Rueda ${ }^{1}$ \\ ${ }^{1}$ UIM en Inmunología, Hospital de Pediatría, CMN Siglo XXI, IMSS, 06720 Mexico City, DF, Mexico \\ ${ }^{2}$ Unidad de Investigación en Virología y Cáncer Hospital Infantil de México Federico Gómez, 06720 Mexico City, DF, Mexico \\ ${ }^{3}$ Departamento de Investigación Experimental y Bioterio del Instituto Nacional de Ciencias Médicas y Nutrición "Salvador Zubirán", \\ 14000 Mexico City, DF, Mexico \\ ${ }^{4}$ UIM en Inmunoquímica, Hospital de Especialidades, CMN Siglo XXI, IMSS, 06720 Mexico City, DF, Mexico \\ ${ }^{5}$ Departamento de Inmunología, ENCB, IPN, 11340 Mexico City, DF, Mexico
}

Correspondence should be addressed to Adriana Karina Chávez-Rueda; akarina.chavezrueda@gmail.com

Received 3 July 2013; Accepted 22 September 2013

Academic Editor: Lenin Pavón

Copyright (C) 2013 Maria Victoria Legorreta-Haquet et al. This is an open access article distributed under the Creative Commons Attribution License, which permits unrestricted use, distribution, and reproduction in any medium, provided the original work is properly cited.

Prolactin (PRL) plays an important role in modulating the immune response. In B cells, PRL enhances antibody production, including antibodies with self-specificity. In this study, our aims were to determine the level of PRL receptor expression during bonemarrow B-cell development and to assess whether the presence of high PRL serum concentrations influences absolute numbers of developing populations and disease outcome in lupus-prone murine models. We observed that the PRL-receptor is expressed in early bone-marrow B-cell; the expression in lupus-prone mice, which had the highest level of expression in pro-B cells and immature cells, differed from that in wild-type mice. These expression levels did not significantly change in response to hyperprolactinemia; however, populations of pro-B and immature cells from lupus-prone strains showed a decrease in the absolute numbers of cells with high PRL-receptor expression in response to PRL. Because immature self-reactive B cells are constantly being eliminated, we assessed the expression of survival factor BIRC5, which is more highly expressed in both pro-B and immature B-cells in response to PRL and correlates with the onset of disease. These results identify an important role of PRL in the early stages of the B-cell maturation process: PRL may promote the survival of self-reactive clones.

\section{Introduction}

Prolactin (PRL) is predominantly produced by the lactotropic cells of the anterior pituitary gland. However, it is also generated in extrapituitary sites, such as immune, decidual, mammary, epithelial, and fat cells [1-3]. PRL has multiple regulatory roles in reproduction, development, growth, osmosis, metabolism of carbohydrates and lipids, and the immune response. The PRL receptor is a member of the cytokine receptor superfamily [3-5]. Different isoforms of the PRL receptor have been found to be generated by alternative splicing at the $3^{\prime}$ end and variation in the intracellular domain length $[3,5,6]$. The PRL receptor is expressed in many immune cell types, mainly B cells, and also $\mathrm{T}$ cells, monocytes, macrophages, natural killer (NK) cells, and thymic epithelial cells $[7,8]$, and its activation induces transcriptional programs involved in various cellular functions such as proliferation, differentiation, and cytokine production. Hence, PRL has been implicated as a modulator of both cellular and humoural immunity [8-11]. 
Elevated serum PRL levels have been reported in several autoimmune diseases, including systemic lupus erythematosus (SLE) [12-14]. SLE is an autoimmune rheumatic disease. Serum samples from SLE patients characteristically have very strong reactivity to a variety of nuclear components, including DNA, RNA, histones, RNP, Ro and La. These antibodies form immune complexes that are deposited in the kidneys and may result in proteinuria and kidney failure. The presence of these autoantibodies indicates abnormalities in the activation and development of B cells $[15,16]$ and both $\mathrm{B}$ and $\mathrm{T}$ cells express the PRL receptor and secrete PRL $[4,17,18]$. SLE affects women of reproductive age at a $9: 1$ ratio compared to men and this gender bias has been attributed to the immunostimulatory properties of hormones. SLE symptoms typically begin or become exacerbated during pregnancy, when PRL serum levels are high. Nonphysiologically high serum concentrations of PRL also correlate with SLE symptoms $[12,14]$. These findings have been reproduced in murine models of lupus (e.g., $(\mathrm{NZB} \times$ NZW)F1 and MRL/lpr), in which the induction of hyperprolactinemia correlated with exacerbated disease symptoms, such as the early detection of autoantibodies, proteinuria and accelerated death $[19,20]$. MRL-MpJFas ${ }^{\text {lpr }}$ (MRL/lpr) mice have a mutation in the Fas gene and develop a disease similar to SLE that is characterised by glomerulonephritis, vasculitis, splenomegaly, hypergammaglobulinemia, and the production of anti-dsDNA antibodies [21]. In this mouse strain, B cell elimination using an anti-CD79 antibody decreased the manifestation of SLE-like symptoms, demonstrating the importance of B cells in SLE physiopathology [22, 23].

B cells develop from hematopoietic stem cells in the bone marrow through a series of differentiation stages. The most immature cell committed to the $\mathrm{B}$ cell lineage is the $\mathrm{B}$ cell progenitor, also called the pro-B cell, which undergoes immunoglobulin heavy chain gene rearrangement and differentiates into a pre-B cell. Pre-B cells undergo immunoglobulin light chain gene rearrangement and develop into immature B cells. This latter population is tested for selfspecificity first in bone marrow then in circulation and the spleen, where it is identified as transitional type I (T-1) B cells. These cells further develop into transitional type II (T2) and type III (T-3) B cells to finally become mature B cells (follicular, and marginal zone cells) [24-27]. B cell antigen receptor assembly and testing for autoreactivity are the primary objectives of B cell development; therefore, the alteration of this maturation pathway results in a generation of $B$ cell clones with the potential to cause autoimmune diseases.

Our group previously demonstrated that T-1 B cells express the highest level of PRL receptor of any other splenic $B$ cell population. We also observed a significant increase in the absolute number of this B cell subset in mice that developed lupus during hyperprolactinemia [20]. Because $\mathrm{T}-1$ s represent the first subset of splenic B cells produced by bone marrow cells, it is possible that PRL targets earlier bone marrow developmental stages. Therefore, the aim of this study was to determine whether developing bone marrow $B$ cells express the PRL receptor and whether development is altered in response to PRL sera levels that correlate with the onset of lupus in a murine model of this disease. Our results showed that all early bone marrow $\mathrm{B}$ cell populations express the PRL receptor. However, the expression was higher in pro-B and immature cells in lupus-prone mice, a pattern that differs from that of wild type mice. Increased levels of PRL hastened disease manifestations, which correlated with a reduction in the absolute number of maturing $\mathrm{B}$ cells. These results support an important role of PRL in the early stages of the B cell maturation process, thus helping to clarify its relevance to the development of SLE.

\section{Materials and Methods}

2.1. Mice. All studies were approved by the Animal Care Committee of Instituto Nacional de Ciencias Médicas y Nutrición "Salvador Zubiran" and Hospital de Pediatría, Centro Médico Nacional Siglo XXI, IMSS (R-2011-785015), and all of the mice experiments were performed in accordance with approved guidelines established by Mexico (Norma Oficial Mexicana NOM-062-ZOO-1999). The C57BL/6 mice were purchased from Harlan (Indianapolis, USA); the MRL/MpJ (MRL) and MRL/MpJFas ${ }^{\text {lpr }}$ (MRL/lpr) mice were purchased from The Jackson Laboratory (Maine, USA). Mice were housed in a pathogen-free barrier facility and were provided with sterile food and water ad libitum.

2.2. Antibodies. The following antibodies were used: APCconjugated rat anti-mouse CD21 (7G6) from BD Biosciences (Mountain View CA, USA); FITC-conjugated rat anti-CD43 (eBioR2160), PE-conjugated rat anti-B220 (RA3-6B2), APCconjugated rat anti-IgM (11/41), PE/Cy7-conjugated rat antiCD23 (B3B4), PE-conjugated rat anti-CD93 (AA4.1), and FITC-conjugated rat anti-CD19 (eBioD3) from eBioscience (San Diego, CA, USA); goat anti-mouse PRL-R (E20) from Santa Cruz Biotechnology (Santa Cruz, CA, USA), and biotinylated swine anti-goat from Invitrogen (Carlsbad CA, USA). The biotinylated secondary antibody was detected using phycoerythrin-Cy5.5 conjugated streptavidin from BD Biosciences (Mountain View, CA, USA). AffiniPure $\mathrm{F}(\mathrm{ab})_{2}$ fragment goat anti-mouse IgM was from Jackson ImmunoResearch (Baltimore, USA).

2.3. Purification of B Cells. Bone marrow (BM) cells were collected by flushing femoral shafts with cold RPMI (HyClone, Logan, Utah, USA) supplemented with $2 \%$ bovine serum albumin (BSA, US Biological, Swampscott, Ma, USA) and EDTA 2 mM (IBI Scientific, USA). After red blood cell depletion using lysis buffer (Sigma Aldrich, St. Louis, Missouri, USA), the cells were incubated with anti-B220 microbeads (Miltenyi Biotec, Bergisch Gladbach, Germany), and B cells were isolated by positive selection using a magnetic activated cell-sorting (MACS) system (Miltenyi Biotec, Bergisch Gladbach, Germany). After purification, $>98 \%$ of the remaining cells were $\mathrm{CD} 19^{+}$by flow cytometry.

2.4. Cell Sorting. B cells suspensions from BM were incubated with fluorescently labelled antibodies specific for CD43, B220, IgM, and CD23 in staining buffer (PBS with 0.5\% BSA) 
for 20 minutes at $4^{\circ} \mathrm{C}$. The cells were washed, and the $\mathrm{B}$ cell $\left(\mathrm{B} 220^{+}\right)$subsets were separated according to the expression of the following surface markers: pro-B $\left(\mathrm{CD} 43^{+}, \mathrm{CD} 23^{-}\right.$, and $\left.\mathrm{IgM}^{-}\right)$, pre-B $\left(\mathrm{CD} 43^{-}, \mathrm{CD} 23^{-}\right.$, and $\left.\mathrm{IgM}^{-}\right)$, and immature cells $\left(\mathrm{CD}_{43}^{-}, \mathrm{CD}^{-} 3^{-}, \mathrm{IgM}^{+}\right)$. Cell sorting was performed using a FACSAria sorter with FACSDiva software (BD Bioscience, Mountain View, CA, USA). The purity of the sorted cells ranged from $95 \%$ to $98 \%$.

2.5. Real Time RT-PCR. Total RNA was extracted from B cells using TRIzol reagent (Invitrogen, Carlsbad, CA, USA) according to the manufacturer's protocol and the RNA concentration was determined using UV spectrophotometry. SuperScript II Reverse Transcriptase (Invitrogen, Carlsbad, CA, USA) was used to generate cDNA from $1 \mu \mathrm{g}$ of total RNA according to the manufacturer's specifications. Genes of interest were amplified and quantified by real time RT-PCR using the LightCyclerTaqMan Master kit (Roche Diagnostic, Mannheim, Germany) according to the manufacturer's specifications. Hydrolysis probes and primers were designed by Roche Diagnostic. The following primers were used: PRL receptor $5^{\prime}$-CAGTAAATGCCACGAACGAA-3' (left), PRL receptor $5^{\prime}$-GAGGAGGCTCTGGTTCAACA-3' (right), $\beta$ actin $5^{\prime}$-AAGGCCAACCGTGAAAAGAT- ${ }^{\prime}$ (left), $\beta$-actin 5'-GTGGTACGACCAGAGGCATAC-3' (right), BIRC5 (survivin) $5^{\prime}$-CCCGATGACAACCCGATA-3' (left) and BIRC5 $5^{\prime}$-CATCTGCTTCTTGACAGTGAGG-3' (right). The final reaction volume was $10 \mu \mathrm{L}$. A LightCycler Instrument (Roche Diagnostic, Mannheim, Germany) was used to perform the RT-PCR reaction. The following RT-PCR conditions were used: 10 minutes at $95^{\circ} \mathrm{C}$, followed by 40 cycles of 10 seconds at $95^{\circ} \mathrm{C}, 30$ seconds at $60^{\circ} \mathrm{C}$ and 1 second at $72^{\circ} \mathrm{C}$ and 1 cycle of 30 seconds at $40^{\circ} \mathrm{C}$. The $\beta$-actin gene was used as a normalisation control across samples. The relative expression of the PRL receptor and BIRC5 were calculated using the 2$\Delta \mathrm{CT}$ formula.

\subsection{Induction of Hyperprolactinemia. Nine-week-old} C57BL/6, MRL, and MRL/lpr mice (8 females per group) were subcutaneously injected with $200 \mu \mathrm{g}$ of metoclopramide (Sigma Aldrich, St. Louis, MO, USA) in $100 \mu \mathrm{L}$ of PBS for six weeks. A matched control group (C57BL/6, MRL and $\mathrm{MRL} / \mathrm{lpr})$ received PBS only $(100 \mu \mathrm{L})$ over the same period. Urinary protein levels were assessed semiquantitatively using reagent strips for urinalysis (UriCheck-10, Axilab, Monterrey, NL, Mex). Serum samples obtained at the beginning and at the end of the experiments were kept at $-35^{\circ} \mathrm{C}$ until they were assayed for PRL and anti-dsDNA antibodies.

2.7. Prolactin Assessment. Serum levels of PRL were detected by ELISA by coating 96-well MaxiSorp plates (Nunc, Rochester, NY, USA) overnight with $100 \mu \mathrm{L}$ of $2 \mu \mathrm{g} / \mathrm{mL}$ anti-mouse PRL monoclonal antibody (clone 207518, R\&D Systems, Minneapolis, MN, USA) in PBS at $4^{\circ} \mathrm{C}$, block with $2 \% \mathrm{BSA}$, and incubat with the serum sample (1:10) overnight at $4^{\circ} \mathrm{C}$. Recombinant mouse PRL (National Hormone and Peptide Program, NIH, donated by AF Parlow) was used as a standard. The plates were then incubated with $0.2 \mu \mathrm{g} / \mathrm{mL}$ biotinylated anti-PRL antibody (R\&D Systems, Minneapolis MN, USA), avidin-conjugated alkaline phosphatase (Invitrogen, Carlsbad, CA, USA) and the enzyme substrate 5-bromo4-chloro-3-indolyl phosphate (Sigma-Aldrich, St. Louis MO, USA) according to the manufacturer's instructions. The OD was measured at $405 \mathrm{~nm}$ using a Dynatech MR5000 ELISA reader.

2.8. Measurement of Anti-dsDNA Antibodies. Anti-dsDNA antibody serum concentrations were detected using ELISA. A 96-well MaxiSorp plate was coated with $100 \mu \mathrm{L}$ of $5 \mu \mathrm{g} / \mathrm{mL}$ calf thymus dsDNA (Sigma Aldrich, St. Louis MO, USA) in bicarbonate buffer overnight at $4^{\circ} \mathrm{C}$ and was blocked with $2 \%$ BSA. The plates were then incubated for $1 \mathrm{~h}$ at $37^{\circ} \mathrm{C}$ with serum $(1: 50)$ or the anti-dsDNA antibody standard (clone 16-13, Chemicon International, Billerica MA, USA), followed by alkaline phosphatase-conjugated rabbit anti-mouse IgG (Invitrogen, Carlsbad, CA, USA) and substrate (5-bromo4-chloro-3-indolyl phosphate). The OD was monitored at $405 \mathrm{~nm}$ using a Dynatech MR5000 ELISA reader.

2.9. Cell Surface Staining and Flow Cytometry. BM cells were incubated with fluorescently labelled antibodies for 20 minutes at $4^{\circ} \mathrm{C}$ in staining buffer (PBS with $0.5 \%$ BSA and $0.01 \%$ sodium azide). The cells were then washed and fixed in 2\% paraformaldehyde (Sigma Aldrich, St Louis MO, USA). The data were acquired using a FACSAria flow cytometer and analysed with FlowJo software (Tree Star, Ashland, OR, USA).

2.10. Statistical Analysis. The data were analysed using standard statistical tests (mean value, SD, Student's $t$-test, and ANOVA) and the results are expressed as the mean \pm SD. The level of significance was set at $P \leq 0.05$. All calculations were performed using SPSS 19 software.

\section{Results}

3.1. Expression of the PRL Receptor in B Cells. The pro-B, pre$\mathrm{B}$, and immature $\mathrm{B}$ cells from the bone marrow of C57BL6 wild-type mice were purified by flow cytometry to $>95 \%$ purity (Figure 1(a)) and were assayed for the expression of PRL receptor mRNA and protein. Our results showed that all $\mathrm{B}$ cell developmental stages in the bone marrow express the $\mathrm{PRL}$ receptor. Immature $\mathrm{B}$ cells had the lowest relative mRNA expression $(0.47 \pm 0.04)$, which was significantly different $(P<0.05)$ compared to pre-B cells $(1.04 \pm 0.18)$ and pro-B cells (1.28 \pm 0.10$)$; there was no significant difference between pro-B and pre-B cells (Figure 1(b)). A similar expression pattern was observed at the protein level; immature B cells had the lowest PRL receptor expression (35.77 $\pm 9.41 \mathrm{MFI}$, mean fluorescence intensity), followed by pre-B cells ( $46.67 \pm$ 6.05 MFI) and pro-B cells (119.30 $\pm 42.51 \mathrm{MFI}$ ) (Figure 2(a)). Thus, PRL receptor expression of pro-B cells is 2.6 times higher than that of pre-B cells and 3.3 times higher than that of immature cells. Figure 2(b) shows the flow cytometry histograms. 


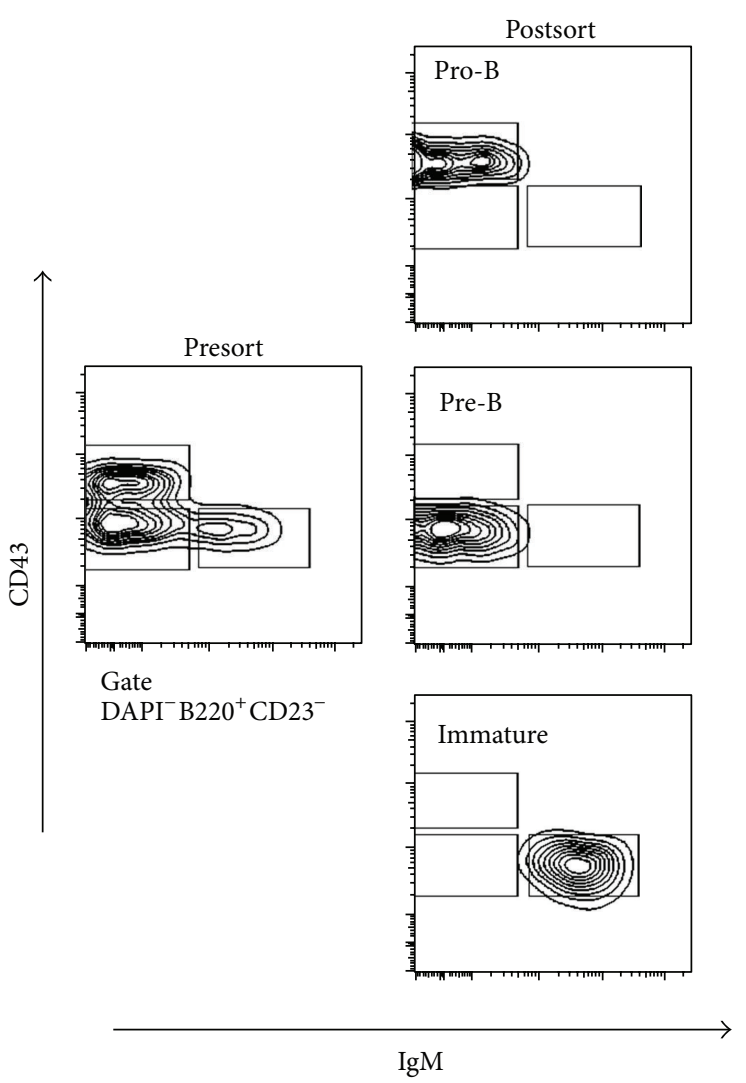

(a)

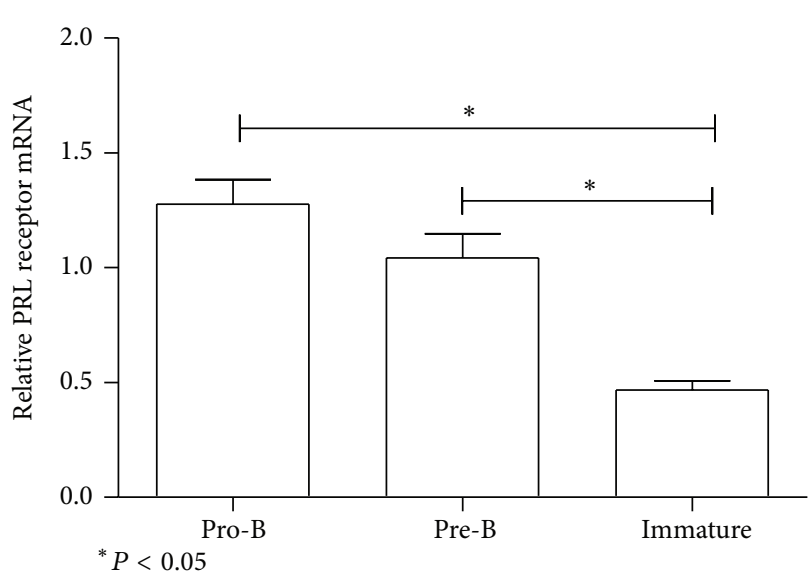

(b)

FIgure 1: Purification of B cell by flow cytometry. B cells were purified from the BM of 9-week-old mice. (a) The cells were incubated with antibodies specific for B cell subsets, and the subsets were purified using flow cytometry, as detailed in Methods. The purity of the collected populations varied between $95 \%$ and $98 \%$. A representative example of the purified B cells from wild-type C57BL/6 mice is shown. (b) Using RT-PCR, the PRL receptor mRNA expression was measured in the different subsets of bone marrow B cells (pro-B, pre-B and immature). The asterisks denote statistical significance with the $P$ value shown.

3.2. Receptor Expression in Lupus-Prone Mice. Analysis of BM $B$ cells from both lupus-prone strains (MRL and MRL/lpr) at 9 weeks of age (without disease manifestations) revealed a different PRL receptor expression pattern; pro-B cells had the highest level of PRL receptor expression (4.5- to 5.5-fold more than pre-Bs and 2.4- to 3-fold more than immature B cells). Thus, in lupus-prone mice, pro-B cells were followed by immature and pre-B cells as shown in Figure 2(c) (MRL: pro-B $=693.60 \pm 46.56 \mathrm{MFI}$, pre-B $=153.40 \pm 37.67 \mathrm{MFI}$, and immature $=288.00 \pm 58.85 \mathrm{MFI})$ and Figure $2(\mathrm{~d})(\mathrm{MRL} / \mathrm{lpr}$ : pro- $\mathrm{B}=385.33 \pm 43.70 \mathrm{MFI}$, pre-B $=77.66 \pm 35.74 \mathrm{MFI}$, and immature $=128.50 \pm 28.73 \mathrm{MFI}$ ); the differences between all populations were statistically significant. In this analysis, MRL mice showed the highest receptor expression, followed by MRL/lpr and C57BL/6 in all BM B cell populations.

3.3. Exacerbation of SLE by Hyperprolactinemia. Nine-weekold MRL/lpr, MRL, and C57BL/6 mice were treated with metoclopramide for six weeks to induce high levels of PRL and accelerate SLE symptoms. The serum concentrations of PRL for pretreatment ( 9 weeks), PBS-treated, and metoclopramide-treated mice were $4.2 \pm 1.38$, $3.80 \pm 1.18$, and $10.70 \pm 1.23 \mathrm{ng} / \mathrm{mL}$, respectively, for the C57/BL6 strain, $12.58 \pm 1.99,11.20 \pm 1.81$, and $26.27 \pm 2.69 \mathrm{ng} / \mathrm{mL}$, respectively, for the MRL strain, and $12.73 \pm 2.25,20.07 \pm 2.75$ and $34.51 \pm 4.34 \mathrm{ng} / \mathrm{mL}$, respectively, for the MRL/lpr strain. All strains had significantly increased PRL levels in sera in response to metoclopramide (hyperprolactinemia), while only MRL/lpr mice showed a significant increase after PBS treatment, which was likely age-related (15 weeks at the end of treatment); however, the PRL increase in the PBS group was lower than in the group treated with metoclopramide (Table 1).

Proteinuria and serum anti-dsDNA antibodies, two disease manifestations that mirror lupus symptoms, were measured and the concentrations were compared between MRL and MRL/lpr mice before and after treatment with metoclopramide or PBS. All mice had a significant increase in proteinuria in response to metoclopramide, while only the PBS-treated group of MRL/lpr mice also showed a significant increase correlating with the observed increase of PRL. This increase in proteinuria was also less dramatic than the increase observed in metoclopramide-treated mice (Table 1). Serum concentrations of anti-dsDNA IgG antibody in hyperprolactinemic MRL mice increased 4-fold compared to PBS 


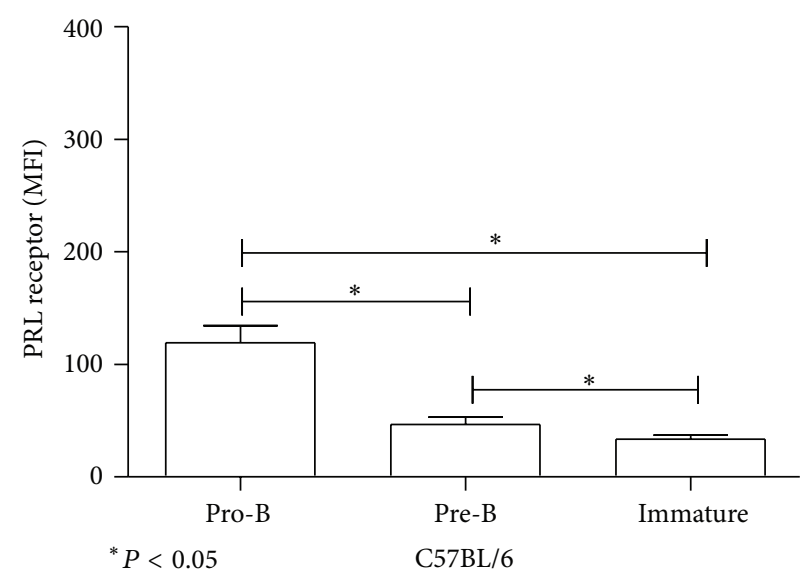

(a)

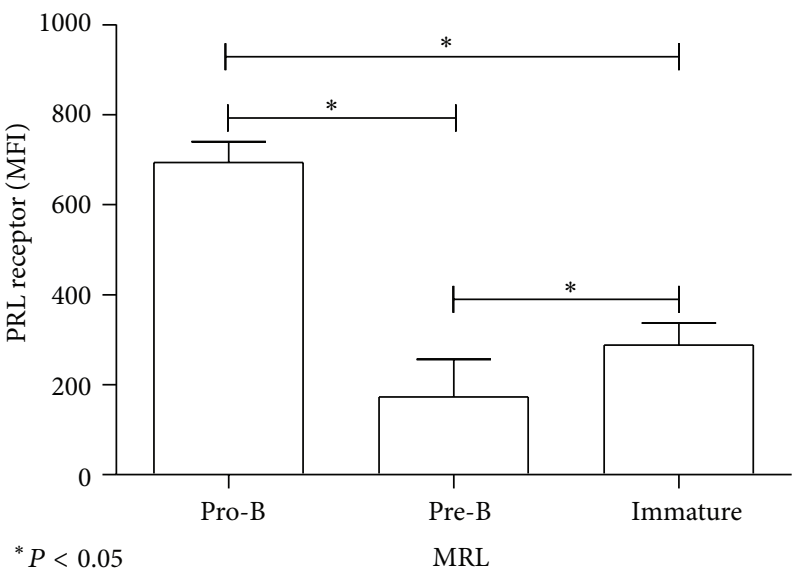

(c)

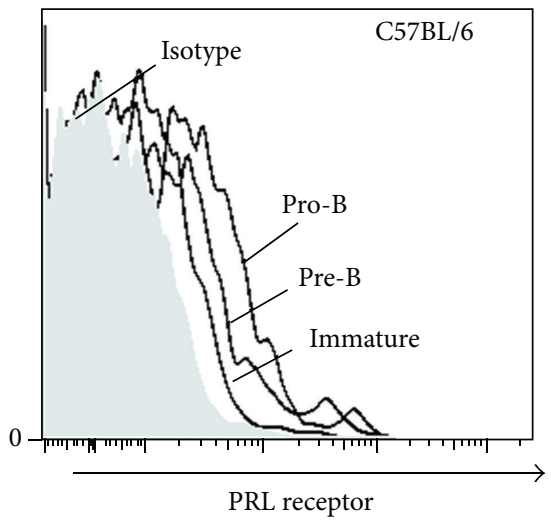

(b)

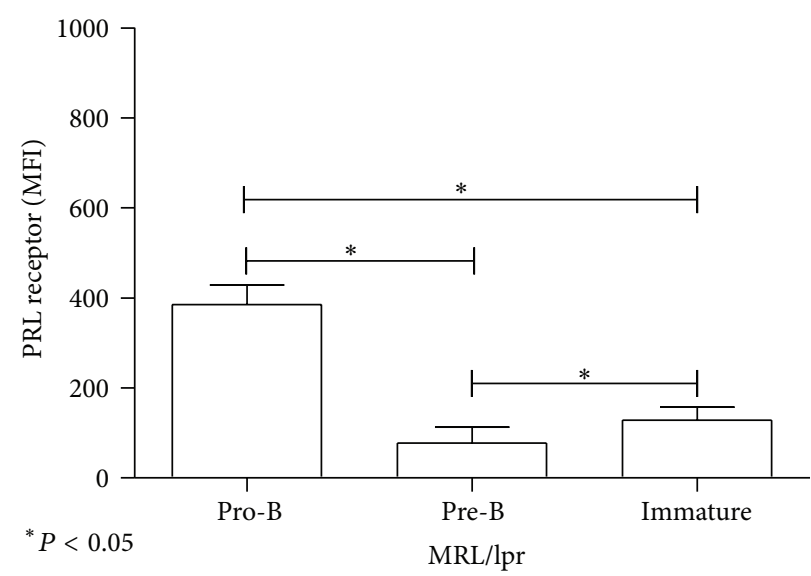

(d)

FIGURE 2: Expression of prolactin receptor in B cells. PRL receptor expression (MFI) was measured using flow cytometry from eight mice per strain. BM cells were labelled with anti-B220, anti-CD43, anti-CD23, anti-IgM, and goat anti-PRL receptor antibodies; the isotype control was labelled with anti-B220, anti-CD43, anti-CD23, anti-IgM, and goat unrelated antibodies. (a) Pro-B, pre-B and immature from C57BL/6 mice; (b) histograms of PRL receptor expression in B cells from BM; (c) pro-B, pre-B, and immature from MRL mice; (d) pro-B, pre-B, and immature from MRL/lpr mice. The asterisks denote statistical significance with the $P$ value shown. The MFI values expressed in the graphs correspond to the MFI values minus the isotype control.

TABLE 1: SLE manifestations in mice with hyperprolactinemia.

\begin{tabular}{lccccccccc}
\hline Strain & \multicolumn{3}{c}{ C57BL/6 } & \multicolumn{4}{c}{ MRL } & \multicolumn{3}{c}{ MRL/lpr } \\
Treatment & 9 weeks & PBS & HyperPRL & 9 weeks & PBS & HyperPRL & 9 weeks & PBS & HyperPRL \\
\hline PRL $(\mathrm{ng} / \mathrm{mL})$ & $4.2 \pm 1.3$ & $3.8 \pm 1.1$ & $10.7 \pm 1.2^{*}$ & $12.5 \pm 1.9$ & $11.2 \pm 1.8$ & $26.27 \pm 2.9^{*}$ & $12.7 \pm 2.2$ & $20.0 \pm 2.7^{*}$ & $34.5 \pm 4.3^{*}$ \\
Proteinuria $(\mathrm{mg} / \mathrm{mL})$ & 0 & 0 & 0 & $10.1 \pm 7.2$ & $12.8 \pm 5.6$ & $121.6 \pm 37.4^{*}$ & $13.5 \pm 8.5$ & $48.0 \pm 18.6^{*}$ & $166.6 \pm 23.5^{*}$ \\
Ab anti-dsDNA $(\mu \mathrm{g} / \mathrm{mL})$ & 0 & 0 & 0 & 0 & $5.9 \pm 1.9^{*}$ & $22.9 \pm 5.1^{*}$ & $2.5 \pm 0.05$ & $11.6 \pm 1.2^{*}$ & $22.5 \pm 5.1^{*}$ \\
\hline
\end{tabular}

HyperPRL: hyperprolactinemia.

*ANOVA, $P<0.05$.

treated mice $(22.96 \pm 5.11$ and $5.94 \pm 1.98 \mu \mathrm{g} / \mathrm{mL}$, resp.). Similarly, MRL/lpr mice showed increased concentrations in hyperprolactinemic and PBS-treated mice (22.50 \pm 5.10 and $11.60 \pm 1.20 \mu \mathrm{g} / \mathrm{mL})$. C57BL/ 6 mice not presented with proteinuria nor anti-dsDNA antibodies in any condition tested (Table 1). Taken together, these data show that increased PRL concentrations in serum correlates with the early onset of lupus symptoms in lupus-prone mouse strains.
3.4. Expression of the Prolactin Receptor in Mice with Hyperprolactinemia. We have previously reported that augmented PRL levels in serum result in higher levels of its receptor in $B$ cell splenocytes [20]. When pro-B, pre-B, and immature cells were analysed, we found that hyperprolactinemia did not change PRL receptor expression in the wild-type control strain (Figure 3(a)). Similarly, there were no significant changes between the PBS and metoclopramide treated groups 


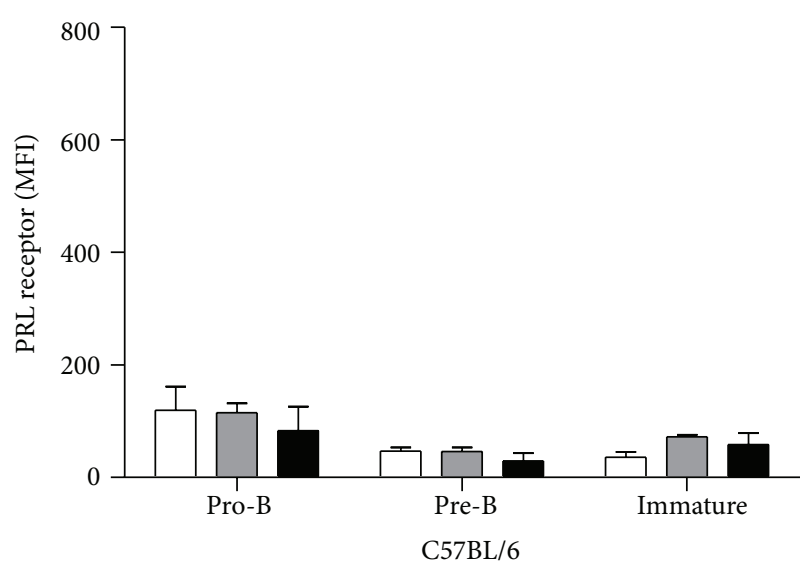

(a)

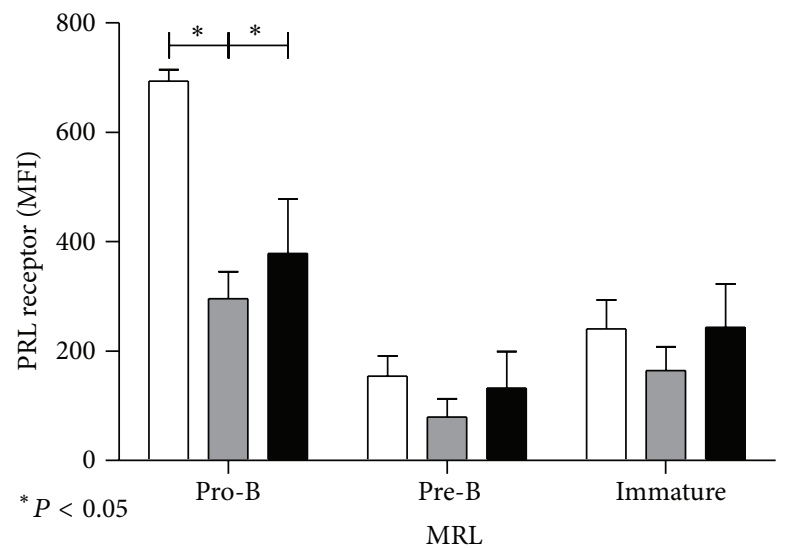

(b)

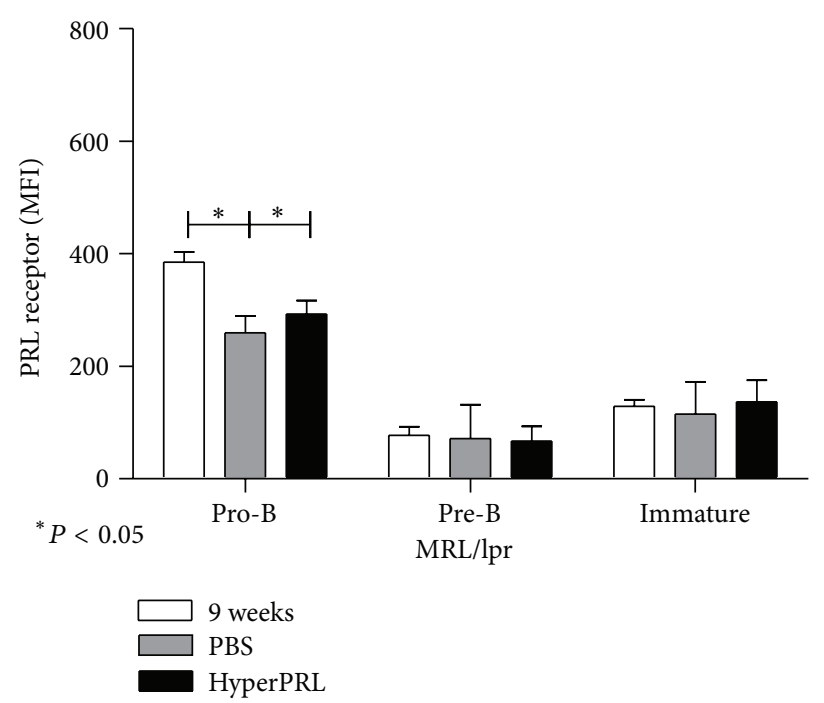

(c)

FIgURE 3: Prolactin receptor expression after the induction of hyperprolactinemia. The levels of PRL receptor protein (MFI) in the B cells from BM (pro-B, preB, and immature) were measured using flow cytometry. At the end of the treatment, the BM cells were labelled with anti-B220, anti-CD43, anti-CD23, anti-IgM, and goat anti-PRL receptor antibodies. (a) C57BL/6 mice; (b) MRL mice; (c) MRL/lpr mice. The asterisks denote statistical significance between populations with the $P$ value shown. The MFI values expressed in the graphs correspond to the MFI values minus the isotype control.

in lupus-prone mice (MRL pro-B cells: $296.00 \pm 49.46$ and $378.66 \pm 79.70 \mathrm{MFI}$, resp.; pre-B cells: $79.50 \pm 33.04$ and $132.50 \pm 66.96 \mathrm{MFI}$, resp.; immature B cells: $164.60 \pm 43.71$ and $221.8 \pm 84.03 \mathrm{MFI}$, resp.; MRL/lpr pro-B cells: $259.80 \pm$ 29.78 and $292.83 \pm 59.50 \mathrm{MFI}$, resp.; pre-B cells: $71.60 \pm 27.00$ and $67.00 \pm 25.98 \mathrm{MFI}$, resp.; and immature B cells: $115.25 \pm$ 28.63 and $136.60 \pm 38.42 \mathrm{MFI}$, resp.) Figures 3(b) and 3(c). In contrast, an age-related significant decrease $(P<0.05)$ was observed in PBS-treated pro-B cells $(\mathrm{MRL}=296.00 \pm 49.46$, $\mathrm{MRL} / \mathrm{lpr}=259.80 \pm 29.78 \mathrm{MFI})$ compared with levels before treatment $(\mathrm{MRL}=693.60 \pm 46.56, \mathrm{MRL} / \mathrm{lpr}=385.33 \pm 43.78$ MFI). This change was larger for MRL than for MRL/lpr mice. Thus, contrary to B cell splenocytes, there is no increase in PRL receptor levels in response to PRL in early $B$ cell populations; instead, there is a decrease in this receptor with age. However, the levels of receptor expression of lupus-prone mice are still significantly higher than those of wild type control mice, especially for pro-B and immature B cells.

3.5. Estimation of Population Absolute Numbers. The absolute cell numbers of bone marrow B cell subsets were analysed as an indicator of possible effects of PRL in B cell development. In C57BL/6 control mice, we did not observe changes in any populations when treated with metoclopramide or PBS. Conversely, mice that developed lupus symptoms had a significant decrease in the absolute number of pro-B cells during hyperprolactinemia $\left(\mathrm{MRL}=0.23 \pm 0.11 \times 10^{6}\right.$ cells, $\left.\mathrm{MRL} / \mathrm{lpr}=0.40 \pm 0.05 \times 10^{6}\right)$ compared with PBS-treated mice $\left(\mathrm{MRL}=0.33 \pm 0.12 \times 10^{6}\right.$ cells, MRL/lpr $=0.53 \pm 0.04 \times 10^{6}$; Figure 4(a)). A decrease was also observed in immature B cells between metoclopramide-treated and PBS-treated mice $\left(\mathrm{MRL}=0.15 \pm 0.07 \times 10^{6}\right.$ and $0.30 \pm 0.08 \times 10^{6}$ cells, resp.; 


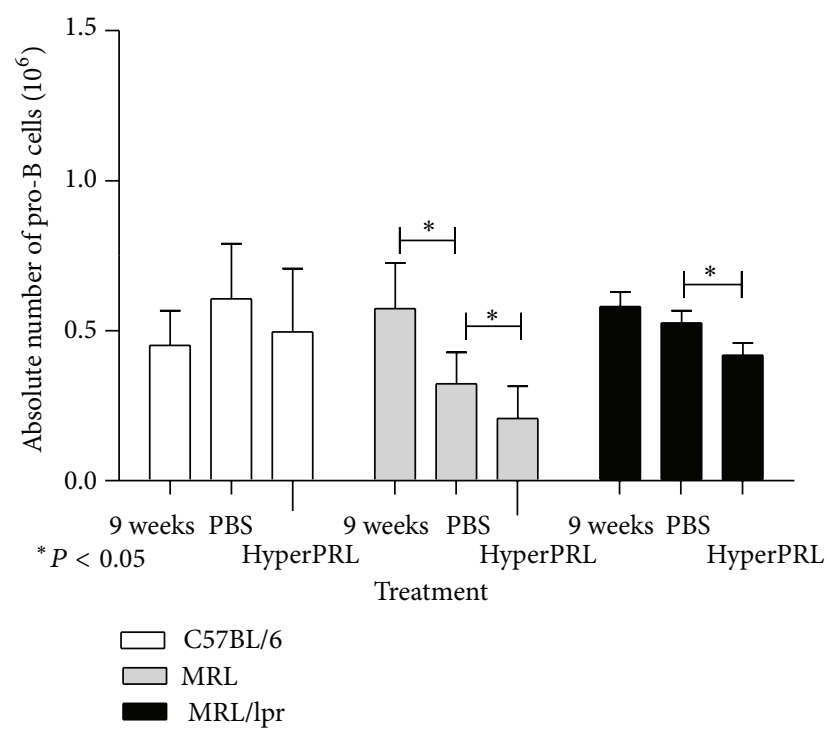

(a)

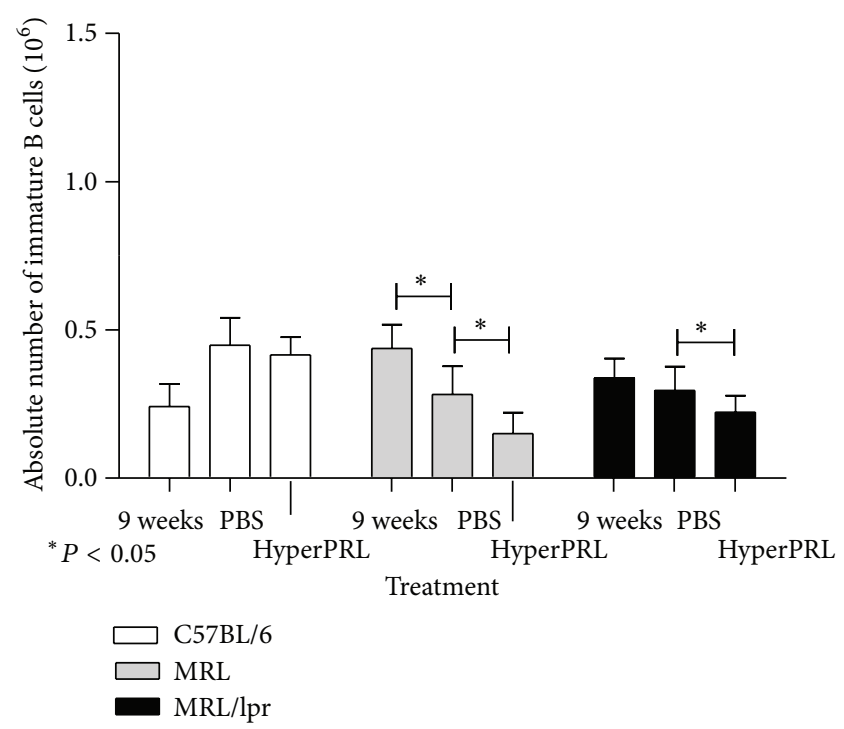

(b)

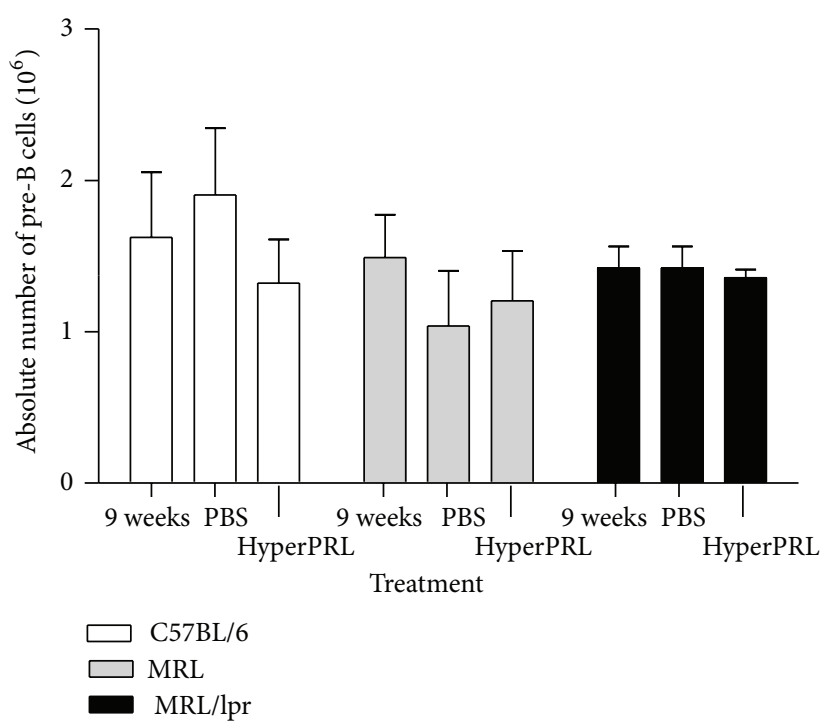

(c)

Figure 4: Absolute number of B cells from bone marrow after the induction of hyperprolactinaemia. Nine-week-old mice were treated with metoclopramide $(200 \mu \mathrm{g} / 100 \mu \mathrm{L})$ to induce hyperprolactinaemia (HyperPRL) or PBS (100 $\mu \mathrm{L})$ for 6 weeks, with eight mice per condition. At the end of the treatment, bone marrow cells were labelled with antibodies against B220, CD43, CD23, and IgM. (a) Graph of the absolute numbers of pro-B cells. (b) Graph of the absolute numbers of immature B cells. (c) Graph of the absolute numbers of pre-B cells. The asterisks denote statistical significance between populations with the $P$ value shown.

$\mathrm{MRL} / \mathrm{lpr}=0.21 \pm 0.06 \times 10^{6}$ and $0.31 \pm 0.08 \times 10^{6}$ cells, resp.; Figure 4(b)). In contrast, the absolute number of pre-B cells was not affected by the hyperprolactinemic state, as shown in Figure 4(c). Therefore, a decrease in the absolute numbers of pro-B and immature $B$ cells seems to correlate with these cells' basal PRL receptor expression (Figure 2). Although we did not observe further changes in receptor expression during hyperprolactinemia, the data in Figure 4 also support a PRLmediated effect.

3.6. Increase in BIRC5 Expression in Immature Cells. Contrary to our previous observations in the spleen, numbers of
BM B cells with higher levels of PRL receptor were reduced in response to PRL. Because self-reacting immature B cells are selected against, it is possible that PRL mediates the accelerated development of immature B cells. Using a gene expression microarray, we previously observed the upregulation of the BIRC5 gene, a survival factor, in total bone marrow cells from 9-week-old MRL/lpr mice cultured in the presence of PRL (manuscript in preparation). Therefore, we assessed whether the expression of this survival factor is altered during hyperprolactinemia. Bone marrow B cell populations were purified and assayed for BIRC5 expression by real time-RTPCR. Figure 5 shows that BIRC5 expression does not vary in 


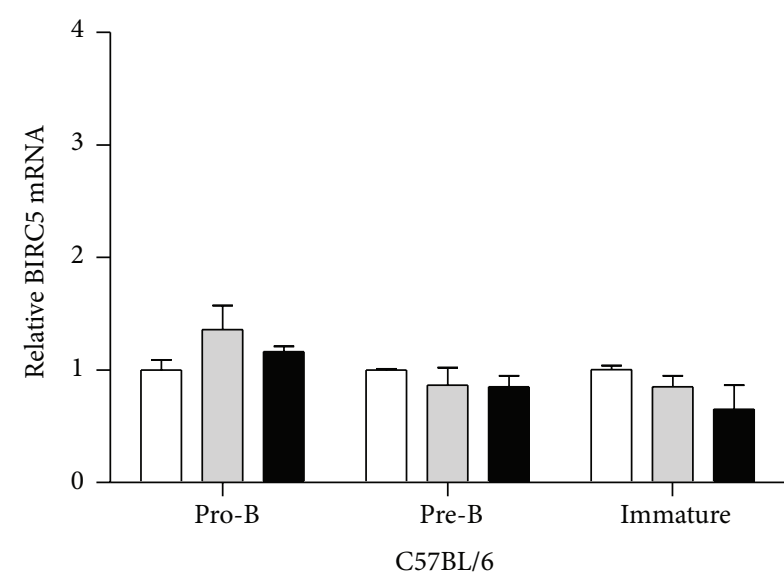

(a)

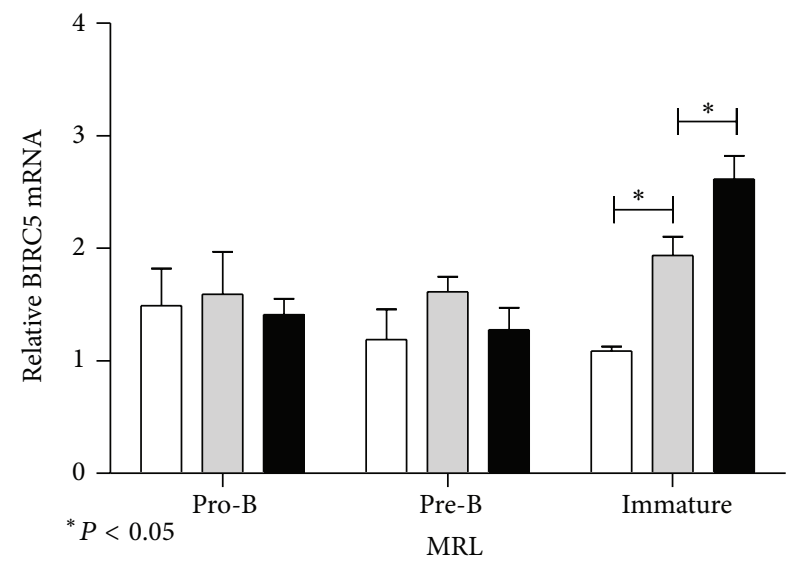

(b)
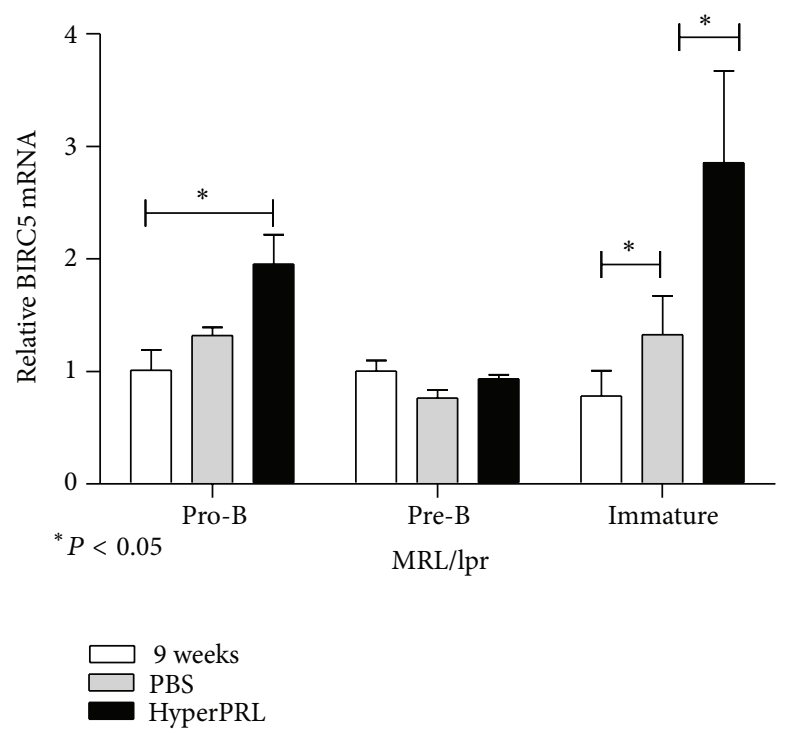

(c)

FIGURE 5: Increase in BIRC5 expression in immature cells. Nine-week-old mice were treated with metoclopramide $(200 \mu \mathrm{g} / 100 \mu \mathrm{L})$ to induce hyperprolactinaemia (HyperPRL) or PBS $(100 \mu \mathrm{L})$ for 6 weeks. At the end of the treatment, pro-B, pre-B and immature B cells were purified using flow cytometry in three independent experiments using three mice per experiment. Using RT-PCR, the BIRC5 mRNA expression was determined. (a) C57BL/6 mice; (b) MRL mice; (c) MRL/lpr mice. The asterisks denote statistical significance between populations with the $P$ value shown.

the control mice (pretreatment $=1.00 \pm 0.03$; PBS-treated $=$ $0.85 \pm 0.10$; and metoclopramide-treated $=0.65 \pm 0.21$; Figure 5(a)), while expression increased in both lupus-prone strains in response to PRL and aging primarily for immature cells (MRL: pretreatment $=1.08 \pm 0.04$; PBS-treated $=$ $1.93 \pm 0.16$; metoclopramide-treated $=2.62 \pm 0.20 ; \mathrm{MRL} / \mathrm{lpr}$ : pretreatment $=0.78 \pm 0.22$; PBS-treated $=1.32 \pm 0.24$; and metoclopramide-treated $=2.85 \pm 0.81$; Figures 5(b) and 5(c)) but also for pro-B cells in the MRL/lpr mice (pretreatment = $1.01 \pm 0.18$; PBS-treated $=1.32 \pm 0.07$; and metoclopramidetreated $=1.95 \pm 0.26$ ). Therefore, a correlation also exists between the expression of the survival factor BIRC5 and basal levels of the PRL receptor. Upregulation of antiapoptotic genes in immature B cells in response to PRL levels may be an important mechanism of escaping tolerance mechanisms and may explain the increase in autoantibodies in PRL-triggered SLE.

\section{Discussion}

Several studies have demonstrated the importance of PRL and B lymphocytes in the development of SLE [12-16]. We previously reported that all subsets of splenic B cells (T-1, T2, T-3, follicular and marginal zone cells) express the PRL receptor, with the highest expression in the most immature subset (T-1s) in the lupus-prone mouse strains [20]. Because $\mathrm{T}-1 \mathrm{~s}$ are directly produced from $\mathrm{B}$ cells developing in the bone marrow, we evaluated the expression of the PRL receptor in different bone marrow developmental stages (pro-B, pre-B and immature) as well as the response of these populations 
to the pharmacological induction of a hyperprolactinemic state and correlated our observations with the course of SLE in MRL/lpr, MRL, and wild-type mice (C57BL/6). We found that bone marrow $B$ cells also express the PRL receptor in all of the mouse strains analysed. However, in wild type mice, the expression of the receptor decreases as the B cell matures, while in strains that develop SLE, immature B cells together with pro-B cells have significantly higher levels of the PRL receptor compared to pre-B cells and their wildtype counterparts. The fact that the PRL receptor is expressed throughout all stages of the $\mathrm{B}$ cell developmental pathway supports the important role of PRL in B cell maturation and therefore in the function of $\mathrm{B}$ cell effectors.

It is known that increased PRL levels favour the appearance of SLE manifestations in NZB $\times$ NZW [28], Sle3/5 R4A- $\gamma 2 \mathrm{~b}$ C57BL/6 [29] and MRL/lpr mice [20]. In MRL and MRL/lpr strains, hyperprolactinemia correlates with premature SLE manifestations as well as increased receptor expression and aberrant B cell development in the spleen [20]. Although we did not observe differences in PRL receptor expression in response to $\mathrm{PRL}$, we observed a reduced number of pro-B, and immature $B$ cells with a high basal PRL receptor expression, indicating a PRL-mediated effect on $\mathrm{B}$ cell development. These data support an association between BM B cell maturation and disease progression. This observation is also supported by reports in which the SLEprone strains MRL/lpr [30], BXSB [31], and NZB [32, 33] presented age-related anomalies in $\mathrm{B}$ cell development that were correlated with disease manifestations [34].

The main goal of $\mathrm{B}$ cell early development is to generate a functional BCR that is not self-reactive and B cell maturation is strongly dependent on either constitutively generated (tonic) signalling or ligand-induced BCR signalling [35]. Increased levels of IL-7 or the ectopic expression of antiapoptotic genes have resulted in the increased proliferation and survival of developing cells, but progression is arrested in the absence of these signals [36]. To our knowledge, there have been no previous in vivo studies of the effect of PRL on early $\mathrm{B}$ cell development. The reduced numbers of pro- $\mathrm{B}$ and immature B cells observed in response to PRL could be due to either accelerated developmental progression or increased negative selection.

Sexual hormones, such as oestrogens, regulate lymphopoiesis; pro-B lymphocytes are especially sensitive to high oestrogen concentrations, resulting in decreased numbers of these cells, where oestrogen can arrest lymphoid lineage differentiation $[37,38]$. A similar PRL effect may explain the reduced numbers of pro-B cells observed during hyperprolactinemia. We also observed decreased numbers of immature B cells, which is an interesting observation because this is one of the main populations subjected to regulation against self-recognition. In transgenic mice in which BCR survival/tonic signals are favoured, for example, the SHIP knockout mice, accelerated development resulting in decreased immature/transitional populations has been observed [39]. PRL-triggered accelerated development throughout the immature stage would also explain our previous observation of the accumulation of T1 B cells in the spleen [20]. PRL may counteract mechanisms that prevent the self-reactivity of immature B cells, facilitating their rapid exit from bone marrow and the feeding of the splenic T-1 pool. Therefore, the results by Morales et al. [40] regarding PRL-induced B cell development argue for B cell maturation coordinated by the BCR together with environmental signals. These latter signals, such as PRL-induced signals, are also critical and may shape the $\mathrm{B}$ cell repertoire in response to different physiological stages.

Ligand-induced BCR signals are often associated with triggering the elimination of autoreactive clones at immature and transitional stages. PRL receptor signalling is known to increase the expression of antiapoptotic genes, such as Bcl-2 [41, 42], and T-1 B cells from hyperprolactinemic $\mathrm{BALB} / \mathrm{c}$ mice are more resistant to apoptosis [43]. In line with these observations, we found that PRL increases the expression of the BIRC5 (survivin) gene (see Supplementary Figure 1 in supplementary material available online at http://dx.doi.org/10.1155/2013/287469), which belongs to a family of apoptosis inhibitors (IAP) [44, 45]. Survivin plays an important role in cell cycle entry/progression, maturation, and the inhibition of apoptosis as well as increasing the survival of hematopoietic stem/progenitor cells [46-50]. An increased expression of BIRC5 in immature B cells was found only in the SLE mice in response to hyperprolactinemia. Furthermore, BM B cells incubated with an anti-IgM antibody have increased survival rates in hyperprolactinemic conditions (Supplementary Figure 2). Taken together, these data indicate an important effect of PRL on B cell development, both favouring positive selection and counteracting mechanisms against self-specificity. In this scenario, increased PRL levels would result in the maturation of $\mathrm{B}$ cell clones with selfreactivity and an increased risk for developing autoimmune diseases. It will be interesting to determine the molecular mechanisms by which PRL and PRL receptors interfere with $\mathrm{B}$ cell maturation and tolerance, which will aid in the rational design of targeted therapy with potential applications for both autoimmunity and immunodeficiencies.

\section{Conclusions}

The PRL receptor is expressed by pro-, pre-, and immature $\mathrm{B}$ cells in the bone marrow suggesting an important role for PRL in early B cell development. In agreement, both populations with increased receptor expression, pro-Bs and immatures, upregulate the expression of survival factor BIRC5 in response to PRL. This might be an important mechanism for breakdown of tolerance, since PRL-enhanced BIRC5 expression correlated with an early onset of lupus symptoms.

\section{Authors' Contribution}

Legorreta-Haquet Maria Victoria and Flores-Fernández Rocio contributed equally to this work.

\section{Acknowledgments}

The authors are very grateful to Dr. A. F. Parlow (National Hormone and Peptide Program, NIH) for providing them 
with recombinant mouse prolactin. This work was supported by Consejo Nacional de Ciencia y Tecnología (no. 150766) and by Fondo de Investigación en Salud (FIS/IMSS/PROT/ G09/767, FIS/IMSS/PROT/G12/1118).

\section{References}

[1] N. Ben-Jonathan, J. L. Mershon, D. L. Allen, and R. W. Steinmetz, "Extrapituitary prolactin: distribution, regulation, functions, and clinical aspects," Endocrine Reviews, vol. 17, no. 6, pp. 639-669, 1996.

[2] E. R. Hugo, T. D. Brandebourg, C. E. S. Comstock, K. S. Gersin, J. J. Sussman, and N. Ben-Jonathan, "LS14: a novel human adipocyte cell line that produces prolactin," Endocrinology, vol. 147, no. 1, pp. 306-313, 2006.

[3] N. Binart, A. Bachelot, and J. Bouilly, "Impact of prolactin receptor isoforms on reproduction," Trends in Endocrinology and Metabolism, vol. 21, no. 6, pp. 362-368, 2010.

[4] C. Bole-Feysot, V. Goffin, M. Edery, N. Binart, and P. A. Kelly, "Prolactin (PRL) and its receptor: actions, signal transduction pathways and phenotypes observed in PRL receptor knockout mice," Endocrine Reviews, vol. 19, no. 3, pp. 225-268, 1998.

[5] M. E. Freeman, B. Kanyicska, A. Lerant, and G. Nagy, "Prolactin: structure, function, and regulation of secretion," Physiological Reviews, vol. 80, no. 4, pp. 1523-1631, 2000.

[6] R. Shao, M. Nutu, B. Weijdegård et al., "Differences in prolactin receptor (PRLR) in mouse and human fallopian tubes: evidence for multiple regulatory mechanisms controlling PRLR isoform expression in mice," Biology of Reproduction, vol. 79, no. 4, pp. 748-757, 2008.

[7] D. W. Montgomery, "Prolactin production by immune cells," Lupus, vol. 10, no. 10, pp. 665-675, 2001.

[8] M. V. Legorreta-Haquet, K. Chávez-Rueda, E. Montoya-Díaz et al., "Prolactin down-regulates $\mathrm{CD} 4{ }^{+} \mathrm{CD} 25^{\text {hi }} \mathrm{CD} 127^{\text {low } /-}$ regulatory T cell function in humans," Journal of Molecular Endocrinology, vol. 48, no. 1, pp. 77-85, 2012.

[9] K. Chavez-Rueda, J. Hérnández, E. Zenteno, A. LeañosMiranda, M. V. Legorreta-Haquet, and F. Blanco-Favela, "Identification of prolactin as a novel immunomodulator on the expression of co-stimulatory molecules and cytokine secretions on T and B human lymphocytes," Clinical Immunology, vol. 116, no. 2, pp. 182-191, 2005.

[10] A. Tomio, D. J. Schust, K. Kawana et al., "Prolactin can modulate $\mathrm{CD} 4^{+} \mathrm{T}$-cell response through receptor-mediated alterations in the expression of T-bet," Immunology and Cell Biology, vol. 86, no. 7, pp. 616-621, 2008.

[11] A. Sodhi and A. Tripathi, "Prolactin and growth hormone induce differential cytokine and chemokine profile in murine peritoneal macrophages in vitro: involvement of p-38 MAP kinase, STAT3 and NF- $\kappa$ B," Cytokine, vol. 41, no. 2, pp. 162-173, 2008.

[12] A. Leaños-Miranda, D. Pascoe-Lira, K. A. Chavez-Rueda, and F. Blanco-Favela, "Persistence of macroprolactinemia due to antiprolactin autoantibody before, during, and after pregnancy in a woman with systemic lupus erythematosus," Journal of Clinical Endocrinology and Metabolism, vol. 86, no. 6, pp. 26192624, 2001.

[13] F. Blanco-Favelal, K. Chavez-Rueda, and A. Leaños-Miranda, "Analysis of anti-prolactin autoantibodies in systemic lupus erythematosus," Lupus, vol. 10, no. 10, pp. 757-761, 2001.
[14] H. Orbach, G. Zandman-Goddard, M. Boaz et al., "Prolactin and autoimmunity-hyperprolactinemia correlates with serositis and anemia in SLE patients," Clinical Reviews in Allergy \& Immunology, vol. 42, no. 2, pp. 1-10, 2011.

[15] T. Dörner, C. Giesecke, and P. E. Lipsky, "Mechanisms of B cell autoimmunity in SLE," Arthritis Research \& Therapy, vol. 13, no. 5, article 243, 2011.

[16] S. Yurasov, H. Wardemann, J. Hammersen et al., "Defective B cell tolerance checkpoints in systemic lupus erythematosus," Journal of Experimental Medicine, vol. 201, no. 5, pp. 703-711, 2005.

[17] V. Goffin, N. Binart, P. Touraine, and P. A. Kelly, "Prolactin: the new biology of an old hormone," Annual Review of Physiology, vol. 64, pp. 47-67, 2002.

[18] H. Güneş and A. M. Mastro, "Prolactin receptor gene expression in rat splenocytes and thymocytes from birth to adulthood," Molecular and Cellular Endocrinology, vol. 117, no. 1, pp. 41-52, 1996.

[19] R. W. McMurray, "Prolactin in murine systemic lupus erythematosus," Lupus, vol. 10, no. 10, pp. 742-747, 2001.

[20] Y. Ledesma-Soto, F. Blanco-Favela, E. M. Fuentes-Panana et al., "Increased levels of prolactin receptor expression correlate with the early onset of lupus symptoms and increased numbers of transitional-1 B cells after prolactin treatment," BMC Immunology, vol. 13, article 11, 2012.

[21] B. Andrews, R. A. Eisenberg, A. N. Theofilopoulos et al., "Spontaneous murine lupus-like syndromes. Clinical and immunopathological manifestations in several strains," Journal of Experimental Medicine, vol. 148, no. 5, pp. 1198-1215, 1978.

[22] O. T. M. Chan, M. P. Madaio, and M. J. Shlomchik, "B cells are required for lupus nephritis in the polygenic, fas-intact MRL model of systemic autoimmunity," Journal of Immunology, vol. 163, no. 7, pp. 3592-3596, 1999.

[23] Y. Li, F. Chen, M. Putt et al., "B cell depletion with anti-CD79 mAbs ameliorates autoimmune disease in MRL/lpr mice," Journal of Immunology, vol. 181, no. 5, pp. 2961-2972, 2008.

[24] T. W. Lebien and T. F. Tedder, "B lymphocytes: how they develop and function," Blood, vol. 112, no. 5, pp. 1570-1580, 2008.

[25] B. Srivastava, R. C. Lindsley, N. Nikbakht, and D. Allman, "Models for peripheral B cell development and homeostasis," Seminars in Immunology, vol. 17, no. 3, pp. 175-182, 2005.

[26] J. Ollila and M. Vihinen, "B cells," International Journal of Biochemistry \& Cell Biology, vol. 37, no. 3, pp. 518-523, 2005.

[27] D. Allman, R. C. Lindsley, W. Demuth, K. Rudd, S. A. Shinton, and R. R. Hardy, "Resolution of three nonproliferate immature splenic B cell subsets reveals multiple selection points during peripheral B cell maturation," Journal of Immunology, vol. 167, no. 12, pp. 6834-6840, 2001.

[28] R. McMurray, D. Keisler, K. Kanuckel, S. Izui, and S. E. Walker, "Prolactin influences autoimmune disease activity in the female B/W mouse," Journal of Immunology, vol. 147, no. 11, pp. 37803787, 1991.

[29] E. Peeva, J. Gonzalez, R. Hicks, and B. Diamond, "Cutting edge: lupus susceptibility interval Sle $3 / 5$ confers responsiveness to prolactin in C57BL/6 mice," Journal of Immunology, vol. 177, no. 3, pp. 1401-1405, 2006.

[30] J. Ohmori, T. Ezaki, and M. Kotani, "Analysis of B-cell abnormalities in autoimmune mice by in vitro culture system using two types of bone marrow stromal cell clone," Immunology, vol. 71, no. 4, pp. 544-550, 1990. 
[31] H. Jyonouchi, P. W. Kincade, and R. A. Good, "Age-dependent changes in B lymphocyte lineage cell populations of autoimmune-prone BXSB mice," Journal of Immunology, vol. 134, no. 2, pp. 858-864, 1985.

[32] S. Yoshida, K. Dorshkind, E. Bearer, J. J. Castles, A. Ahmed, and M. E. Gershwin, "Abnormalities of B lineage cells are demonstrable in long term lymphoid bone marrow cultures of New Zealand black mice," Journal of Immunology, vol. 139, no. 5, pp. 1454-1458, 1987.

[33] Z.-X. Lian, H. Kita, T. Okada et al., "Increased frequency of pre-pro B cells in the bone marrow of New Zealand black (NZB) mice: implications for a developmental block in B cell differentiation," Developmental Immunology, vol. 9, no. 1, pp. 35-45, 2002.

[34] K. Nakatani, W.-M. Qu, M.-C. Zhang et al., "A genetic locus controlling aging-sensitive regression of B lymphopoiesis in an autoimmune-prone MRL/lpr strain of mice," Scandinavian Journal of Immunology, vol. 66, no. 6, pp. 654-661, 2007.

[35] C. Eschbach, M. P. Bach, I. Fidler et al., "Efficient generation of B lymphocytes by recognition of self-antigens," European Journal of Immunology, vol. 41, no. 8, pp. 2397-2403, 2011.

[36] K. Ochiai, M. Maienschein-Cline, M. Mandal et al., "A selfreinforcing regulatory network triggered by limiting IL-7 activates pre-BCR signaling and differentiation," Nature Immunology, vol. 13, no. 3, pp. 300-307, 2012.

[37] P. W. Kincade, K. L. Medina, K. J. Payne et al., "Early Blymphocyte precursors and their regulation by sex steroids," Immunological Reviews, vol. 175, pp. 128-137, 2000.

[38] K. L. Medina, K. P. Garrett, L. F. Thompson, M. I. D. Rossi, K. J. Payne, and P. W. Kincade, "Identification of very early lymphoid precursors in bone marrow and their regulation by estrogen," Nature Immunology, vol. 2, no. 8, pp. 718-724, 2001.

[39] A. Brauweiler, I. Tamir, J. Dal Porto et al., "Differential regulation of B cell development, activation, and death by the Src homology 2 domain-containing $5^{\prime}$ inositol phosphatase (SHIP)," Journal of Experimental Medicine, vol. 191, no. 9, pp. 1545-1554, 2000.

[40] P. Morales, M. V. Carretero, H. Geronimo et al., "Influence of prolactin on the differentiation of mouse B-lymphoid precursors," Cell Growth and Differentiation, vol. 10, no. 8, pp. 583-590, 1999.

[41] A. R. Buckley, "Prolactin, a lymphocyte growth and survival factor," Lupus, vol. 10, no. 10, pp. 684-690, 2001.

[42] S. K. Kochendoerfer, N. Krishnan, D. J. Buckley, and A. R. Buckley, "Prolactin regulation of Bcl-2 family members: increased expression of bcl-xL but not mcl-1 or bad in Nb2-T cells," Journal of Endocrinology, vol. 178, no. 2, pp. 265-273, 2003.

[43] S. Saha, J. Gonzalez, G. Rosenfeld, H. Keiser, and E. Peeva, "Prolactin alters the mechanisms of B cell tolerance induction," Arthritis and Rheumatism, vol. 60, no. 6, pp. 1743-1752, 2009.

[44] T. E. Dohi, E. Beltrami, N. R. Wall, J. Plescia, and D. C. Altieri, "Mitochondrial survivin inhibits apoptosis and promotes tumorigenesis," Journal of Clinical Investigation, vol. 114, no. 8, pp. 1117-1127, 2004.

[45] K. Toyonaga, H. Kikuchi, K. Yamashita, M. Nakayama, K. Chijiiwa, and T. Nakayama, "E2A participates in a fine control of pre-mature B-cell apoptosis mediated by B-cell receptor signaling via transcriptional regulation of survivin, IAP2 and caspase-8 genes," FEBS Journal, vol. 276, no. 5, pp. 1418-1428, 2009.

[46] S. Fukuda and L. M. Pelus, "Regulation of the inhibitor-of-apoptosis family member survivin in normal cord blood and bone marrow CD $34^{+}$cells by hematopoietic growth factors: implication of survivin expression in normal hematopoiesis," Blood, vol. 98, no. 7, pp. 2091-2100, 2001.

[47] S. Fukuda and L. M. Pelus, "Elevation of Survivin levels by hematopoietic growth factors occurs in quiescent $\mathrm{CD} 34^{+}$hematopoietic stem and progenitor cells before cell cycle entry," Cell cycle, vol. 1, no. 5, pp. 322-326, 2002.

[48] S. Fukuda, R. G. Foster, S. B. Porter, and L. M. Pelus, "The antiapoptosis protein survivin is associated with cell cycle entry of normal cord blood CD $34^{+}$cells and modulates cell cycle and proliferation of mouse hematopoietic progenitor cells," Blood, vol. 100, no. 7, pp. 2463-2471, 2002.

[49] F. Altznauer, S. Martinelli, S. Yousefi et al., "Inflammation-associated cell cycle-independent block of apoptosis by survivin in terminally differentiated neutrophils," Journal of Experimental Medicine, vol. 199, no. 10, pp. 1343-1354, 2004.

[50] S. Gurbuxani, Y. Xu, G. Keerthivasan, A. Wickrema, and J. D. Crispino, "Differential requirements for survivin in hematopoietic cell development," Proceedings of the National Academy of Sciences of the United States of America, vol. 102, no. 32, pp. 11480-11485, 2005. 


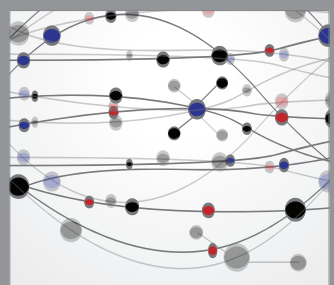

The Scientific World Journal
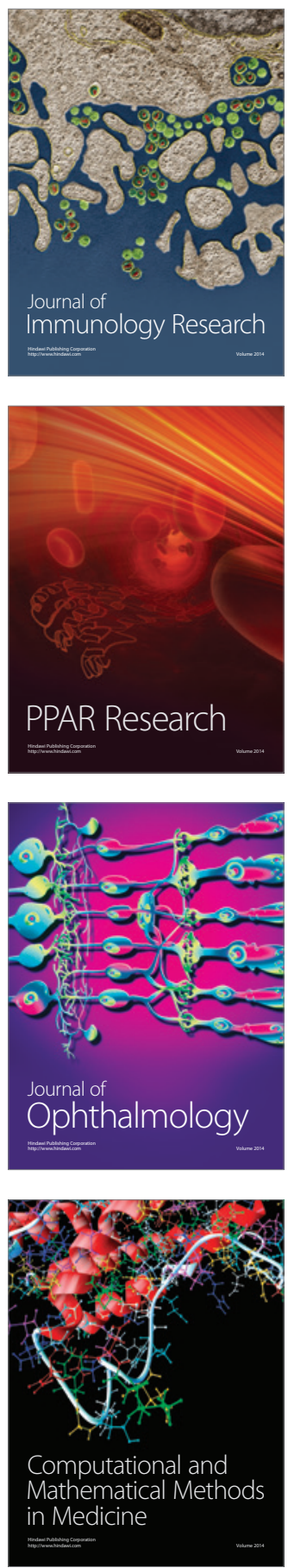

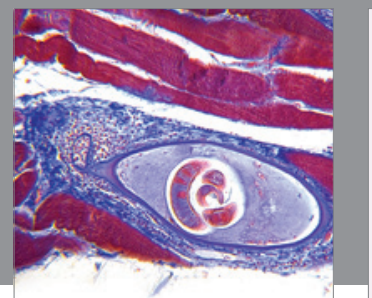

Gastroenterology

Research and Practice
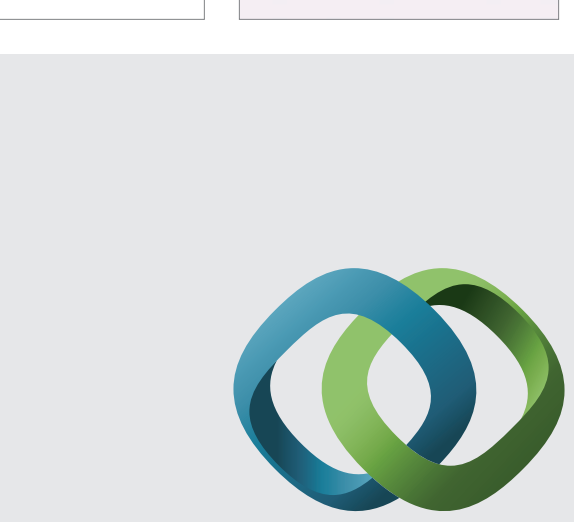

\section{Hindawi}

Submit your manuscripts at

http://www.hindawi.com
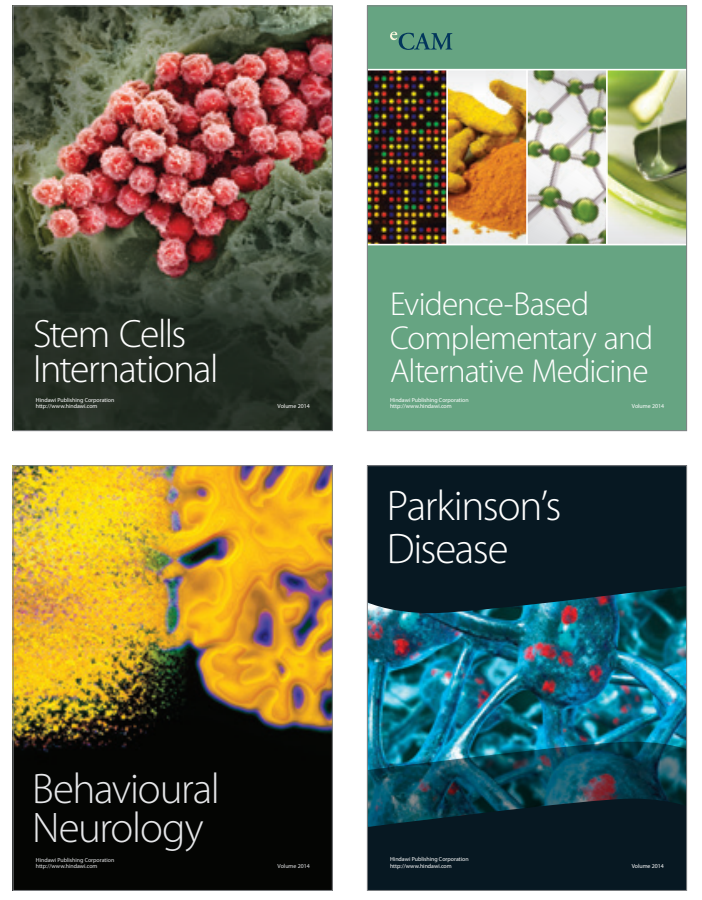
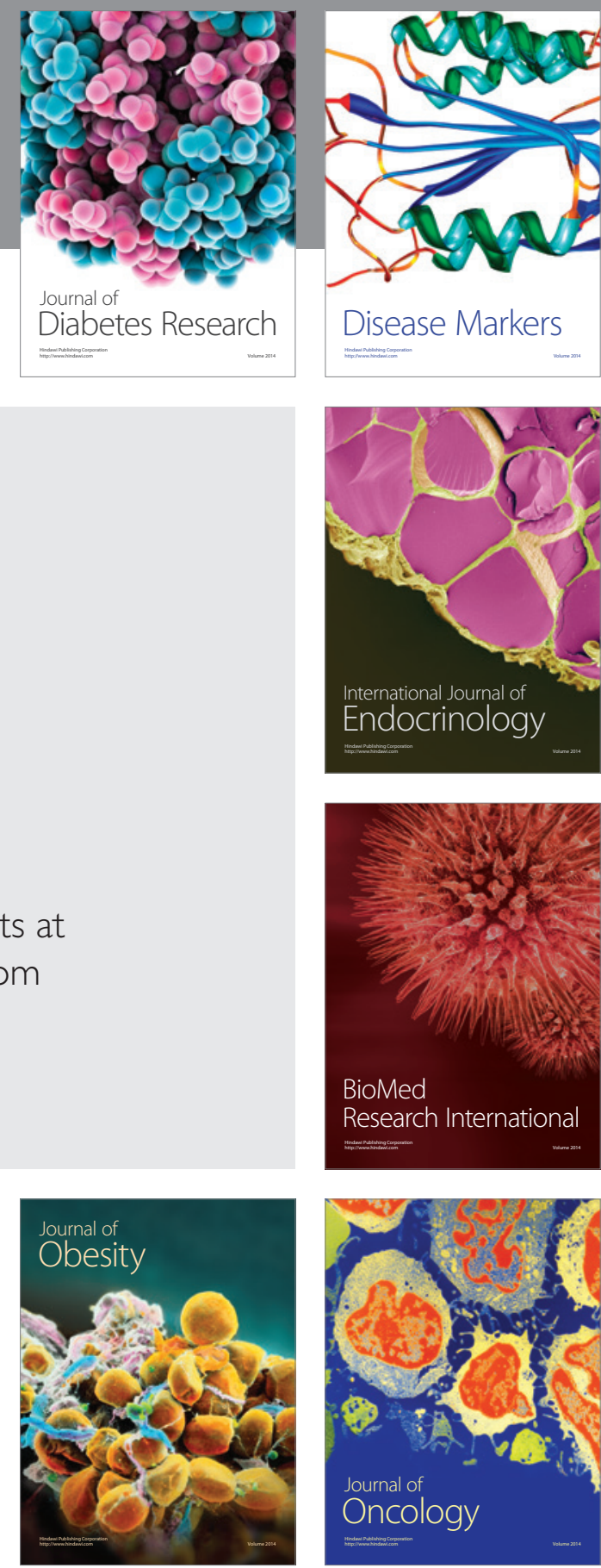

Disease Markers
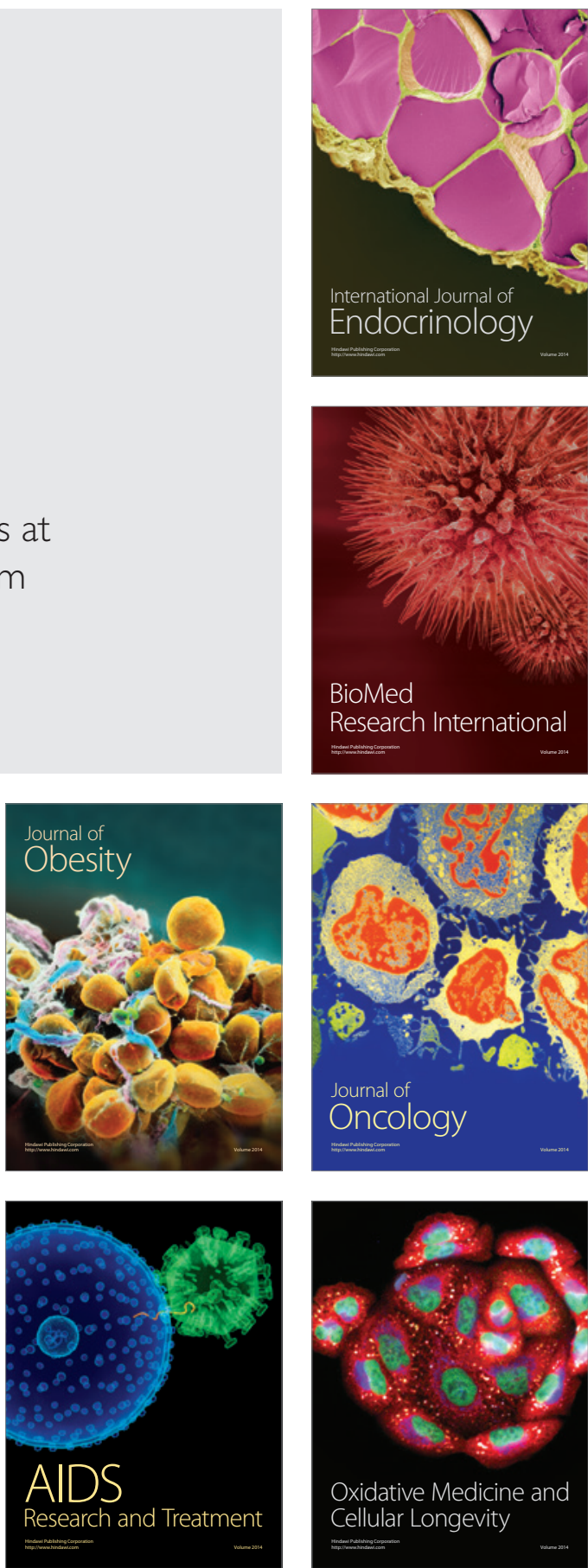